medicine for non-medical layment. It takes both lawyers and others who are interested (and that should include many doctors) in detail through all the steps both before and during an action for what is loosely called 'medical negligence', and comments pithily on the various stages of this forensic obstacle race. Perhaps these quotations will give the flavour:

'Instructing an expert. This is the Beecher's Brook of your action. We could even say, a little unkindly, that it can be the pons asinorum!. . . You need an expert of the right specialty, who can write a thorough and intelligible report that can withstand cross-examination, who achieves a happy mean between seeking to exculpate a colleague and over-egging the plaintiff's pudding in an effort to come up with the goods, who is familiar with the requirements of litigation and appearing in court and who will make a good witness' ( $p 80$ ).

'... the determining factor will be the judge's view as to whether justice dictates recovery [of damages, that is, rather than to health]. He will then find a legal peg on which to hang his decision. ... The progress of law within a society is always from formalism to flexibility, albeit that in the common law tradition judicial activism is usually disguised by an artfully contrived appearance of deference to authority' (pp 172-173).

(THE LATE) PAUL SIEGHART, Honorary Visiting Professor of Law, King's College, London (KQC)

\section{Embryos and Ethics: The Warnock Report in Debate}

Edited by Nigel $M$ de $S$ Cameron, 122 pages, Edinburgh, $£ 5.90$, Rutherford House Books, 1987.

This collection of articles appears from internal evidence to originate in a conference at Rutherford House in Edinburgh, of which the editor is warden. One of the articles, by $\mathrm{Dr}$ Teresa Iglesias, has already appeared in this journal, and six others in Ethics and Medicine. It is therefore only in a rather specialised sense a new publication.

Nor is the reference in the subtitle to 'debate' entirely accurate. This is a highly partisan document, gathering together a variety of expressions of what is essentially the same point of view, that human life begins at conception, and that research on the embryo must in consequence be ruled out. The editor's opening essay is entitled 'The Christian Stake in the Warnock Debate'; both the title and the essay convey the clear message that this point of view represents the Christian stance on the issues under discussion. In only one article, reviewing the churches' responses to the Warnock Report, is there a real attempt to describe and evaluate other points of view held within the churches. Incidentally, the author, Dr Isobel Grigor, is wrong in stating ( $p$ 85) that among the churches responding to the report 'there is unanimous rejection of third party donation on ethical grounds'. That may have been true of the Scottish churches: the Church of England's Board for Social Responsibility, by a majority, agreed with Warnock that " "those engaging in AID are, in their own view, involved in a positive affirmation of the family" and hence AID may be regarded as an acceptable practice'.

There is a polemical piece by the late Professor Ian Donald. He characterises the report as a 'totally secular, irreligious type of report which would satisfy any atheist . . . one should not be deceived by its mellifluence'.

Despite these defects, however, Embryos and Ethics is valuable for the searching attention it gives to a number of central issues in this field. Two deserve special note. Richard Higginson's discussion of the ethics of experimentation on human subjects acknowledges that proxy consent may on occasion be necessary, and is in his view consistent with the main thrust of the ethical tradition. His opposition to experiments on embryos is based on the fact that avoidance of harm to the subject, an integral part of the ethical code of the 1975 Declaration of Helsinki, cannot possibly be honoured where the embryo is concerned. 'Such harm is not unlikely, insignificant, or insubstantial. It is harm with a capital $\mathrm{H}$ - wounding, malignant and deadly.' It is a weakness of those ethical analyses which relate the protection afforded to the embryo and fetus to the stages of embryonic and fetal development, that they blur the distinction between relative protection and absolute harm. It would be preferable to state clearly that improvements in the care of some embryos and fetuses are being sought at the expense of others.

In the contributions by the editor and Dr David Atkinson there is a helpful discussion of what is involved in discerning moral significance in human beings. They are both clear that that significance does not derive from specifiable characteristics such as consciousness, rationality or the like, but from our common call to enter into relationship with God. To be made in the image of God is to be addressed by him, to be related to him. This is common to the human species and unique to it. As Dr Atkinson points out, Christians are 'obliged to make this fundamental discrimination' stigmatised as 'speciesism' by some philosophers.

The Warnock Report chose to bypass this fundamental debate. It can be criticised for doing so. But there remains an impasse in communication between those who, either explicitly or implicitly, endorse the understanding of what it is to be human just mentioned, and those who opt for a more instrumental view. This book is helpful in the way it clarifies some of the areas of dispute: something different, of a different temper, is needed if the extent of common ground is to be mapped and enlarged.

REVD GILES ECCLESTONE, Over Vicarage, Cambridgeshire

\section{The Use of Human Beings in Research}

Edited by SF Spicker, I Alon, A de Vries, and H T Engelhardt, 291 pages, Dordrecht, £43.00,

Kluwer Academic Publishers, 1988.

One of the questions that I ask referees for the journal I edit is 'Has the author made an attempt to communicate to the non-specialist?' I fear that the answer in this case would be 'No'. Too much of this book reads as if it had been transcribed from a conversation between a collection of lawyers and sociologists called together to impress each other on the conference circuit.

This particular conference took place in September 1982 in Tel Aviv. I should have liked to have been there, for there is no doubt in my mind that I should have regarded these papers as a perfect excuse to make for the beach. The six years that have passed since the conference have not been spent polishing the prose.

The story of Daniel and his friends who only ate Kosher food yet looked healthier than the young men fattened up by Nebuchadnezzar is cited as the 
first clinical trial. True to form it is reprinted in the turgid prose of the New English Bible. However, the modern interest in the ethics of human experimentation dates from the Nazi concentration camps, and the legacy of Nuremberg permeates this volume. Robert Massey puts the history of experimentation in cultural context and cautions us against the use of the retrospectoscope in judgement. Engelhardt argues fairly cogently that randomised clinical trials are not intrinsically unethical, comparing the patient who consents to enter one with the man who joins a poker school and thereby agrees to have his fellow players attempt to deceive him. Unfortunately, this essay like many in the volume assumes a familiarity with the work of Hans Jonas. I would strongly advise anyone who is unfamiliar with it not to bother with this book.

Spicker argues against randomised trials before pilot trials have set out the ground rules - all very sensible. The essay by Michael Ruse on interrupting clinical trials is the first statistical paper in the volume and the first one I really warmed to.

Is there an obligation to participate in biomedical research? Arthur Copplan makes the (theological) point that to be the recipients of the benefits of someone else's sacrifice does not make us debtors. We are only obliged to be grateful, not to sacrifice ourselves.

The Dagis caution us against autoexperimentation, and Ladimer reduces the harm done by experiments to mere money.

This really is the sort of book that you only read because you've been asked to review it.

PROFESSOR T J HAMBLIN Professor of Immunohaematology Southampton University 15 Queens Park South Drive Bournemouth

\section{The Nazi Doctors}

Robert Jay Lifton, 561 pages, London, $£ 9.95$, Papermac, a branch of Macmillan, 1987

This long and important book is divided into three parts. Part I, Life Unworthy of Life, is basically about eugenic euthanasia, and recounts how in this field, before proceeding to the next step - the Nazi extermination of Jews and other groups such as gypsies - doctors were involved at all stages of the euthanasia project.
Part II, entitled Auschwitz, the Racial Cure, consists of detailed accounts of interviews with many of the doctors who themselves were Nazis, and who, often by means of slow induction into the lethal system, became adapted to it. They did so in various ways, some being totally involved in an almost religiously fanatical way with the aim of cleansing and perfecting the German people. This was completely in line with Hitler's dream as stated in Mein Kampf and repeated many times thereafter. Some doctors carried out their tasks, which led to the deaths of innumerable humans with less than relish, while others were able to be relatively kind and overtly healing but always within the general ambience of 'licensed mass murder' on a mega-scale. The author calls this duality, this polarisation, 'doubling' by the doctors into twin selves, a sort of Dr Jekyll and Mr Hyde effect. Dissociation or splitting was responsible for this. Seriously disturbing though all the book is, one of the most worrying parts is the way in which some of the prisoner-doctors called upon - or 'privileged' - to help in the camp, were drawn into the vortex of the Racial Cure, which consisted of the most massive genocidal organisation the world has ever known.

Thus, some of the prisoner-doctors, while remaining concerned with being healers in one way, suffered from doubling too, so that they could cooperate in the lethal project with their 'other selves'. This had an element of self-preservation in it, but the situation was more complicated than that. It shows the power of the group, and the institutional dynamics of an extermination camp.

Part III, The Psychology of Genocide, is much shorter than Part II, but is the most interesting part of the book. A part of each doctor who eventually became adapted to the Auschwitz ethos did so at the cost of part, or in some cases nearly all, of his basic humanity. This involved a breakdown of the balance of life and death instincts within him, with a massive bias towards death. Identification with the aggressor in the interests of self-preservation was the general reaction. When these medical staff members were so reacting, preserving the self was accomplished for the time being by a massive putting of death into the concentration camp inmates; it was they, the inmates, who were killed, not the doctor's own 'self', and the process was repeated many, many times upon a succession of victims.

In order to make this abattoir of humanity efficient in carrying out the $\overrightarrow{\bar{D}}$ most grisly of work, the inmates were herded, de-humanised by brutal $\Rightarrow$ treatment, including hard physical of work and gross starvation, so that theyo were helped to be less than human $\frac{C}{0}$ before they were killed. This facilitated $\overline{\bar{\omega}}$ the killing of them so that it could be $\overrightarrow{\widetilde{D}}$ fitted loosely into the euthanasia $\propto$ project. The doctors tried to make their कै role have some compatibility with their $\overrightarrow{0}$ Hippocratic oath, some conformity with it, but it was an unconvincing and $\overrightarrow{\vec{\omega}}$ dishonest self-protecting edifice of $\stackrel{\vec{\omega}}{ }$ confused rationalisation. In order to $\overrightarrow{3}$ carry on, the phenomenon labelled by $\Phi$ the author as 'doubling' took place. $\vec{G}$ Thus, the doctor was split and polarised $-\overrightarrow{.}$ into a reasonably compassionate and ir genial self, the Dr Jekyll self, and the Nazi officer caught in the machine of mass murder, became the Mr Hyde character. The whole rationale of The $\vec{T}$ Final Solution, and prior to that of the 'this person is not fit to live' of the euthanasia campaign, appears to be based on the projection of all the $\vec{\varphi}$

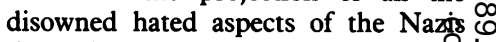
themselves, into victims labelled Jewor gypsies, mentally subnormals psychotics, and there and then was tit slaughter: they were killed. I am reminded of the factors that I and others $\varrho$ have found in the minds of multiple $\subseteq$ murderers. In Auschwitz the situation $\overrightarrow{\vec{A}}$ was highly organised on a colossal scale. The most horrendous feature of it was a combination of a confused racial selfidealisation, with a massive denigration of categories of people designated as suitable only for extermination, and the efficient carrying out of the programme of annihilation.

Everyone should read this book and $\delta$ face the painful question: 'How would I 3 have behaved as a doctor in Auschwitz, 웅 and how would I have behaved as a prisoner-doctor?’

ARTHUR HYATT WILLIAMS, N Consultant, Camden Psychotherapy Unit, ㅇ Medical Psycho-analyst $\omega$

Health and Medicine
in the Islamic
Tradition

Fazlur Rahman, 150 pages, New York, $\stackrel{\mathbb{Q}}{\varrho}$ $\$ 18.95$, Crossroad Publishing Co, 1987.

There are six major religions in the 